RADOVI

Zavoda za znanstveni rad

HAZU Varaždin

IVAN KOVAČ

Sveučilište u Zagrebu, Geotehnički fakultet Varaždin
UDK 628.1:556.3(497.523)

Izvorni znanstveni članak

Original Scientific Paper

Primljeno: 30. 06. 2016.

Prihvaćeno: 20. 06. 2017. DOI: http://doi.org/10.21857/9e31lh4zem

BARICA KOVAČEV-MARINČIĆ

Sveučilište u Zagrebu, Geotehnički fakultet Varaždin

bkovacev@gfv.hr

NIKOLINA NOVOTNI-HORČIČKA

Varkom d. d. Varaždin

laboratorij@varkom.com

JOSIP MESEC

Sveučilište u Zagrebu, Geotehnički fakultet Varaždin

josip.mesec@gfv.hr

JELENA VUGRINEC

Sveučilište u Zagrebu, Geotehnički fakultet Varaždin

jelena.vugrinec.1992@gmail.com

\title{
KOMPARATIVNA ANALIZA KONCENTRACIJE NITRATA U GORNJEM I DONJEM SLOJU VARAŽDINSKOG VODONOSNIKA
}

Analizirana je koncentracija nitrata u podzemnoj vodi Varaždinskog vodonosnika. Utvrđena je statistički značajna razlika između koncentracije nitrata u proom i drugom vodonosnom sloju. To ukazuje na veću izloženost gornjeg sloja onečišćenju i zaštitu donjeg sloja koju pruža slabopropusni međusloj.

\section{UVOD}

Na području Varaždinske i Međimurske županije nalazi se pet crpilišta namijenjenih za javnu vodoopskrbu na kojima se podzemna voda crpi iz Varaždinskog vodonosnika. Na varaždinskom području to su crpilišta Varaždin, Bartolovec i Vinokovščak, a na području Međimurja crpilišta Nedelišće i Prelog (slika 1.). Sa 
stanovišta kakvoće podzemne vode Varaždinskog vodonosnika problematične su povišene koncentracije nitrata. Najkritičnije je stanje na crpilištu Varaždin gdje je koncentracija nitrata u podzemnoj vodi povećana do te mjere da je već dugi niz godina prekoračena najveća dopuštena koncentracija (MDK) od $50 \mathrm{mg} / \mathrm{L} \mathrm{NO}_{3}$ - određena Pravilnikom o parametrima sukladnosti i metodama analize vode za ljudsku potrošnju (NN 125/2013, 141/2013, 128/2015). Zbog toga je crpilište Varaždin danas gotovo izvan funkcije i podzemna voda se crpi samo povremeno u razdobljima najveće potražnje. Na ostalim crpilištima koncentracija nitrata manja je od MDK.

Kao glavni uzroci prekomjerne koncentracije nitrata u podzemnoj vodi na crpilištima Varaždin i Bartolovec smatraju se primjena mineralnih i organskih gnojiva, posebno pilećeg gnoja, na poljoprivrednim površinama, neadekvatno zbrinjavanje otpada iz stočarskih i peradarskih farmi, procjeđivanje otpadnih voda iz septičkih jama i kanalizacijske mreže te blizina groblja (Urumović i dr., 1990; Grđan i dr., 1991; Gjetvaj, 1993; Kovač, 2004; Marković i dr., 2007; Larva, 2008; Šrajbek, 2011a; Šrajbek, 2011b). Posredan utjecaj imala je i izgradnja hidroelektrana na rijeci Dravi koja je uzrokovala promjenu razina podzemne vode u njihovom zaobalju (Grđan, 1989; Grđan i Kovačev,1989). S jedne strane, povišenje razine podzemne vode nakon punjenja akumulacijskih jezera hidroelektrana dovelo je do ispiranje nitrata iz do tada nesaturirane zone vodonosnika (Grđan i dr., 1991), a s druge strane rezultiralo je promjenom smjerova tečenja u plitkom vodonosniku i naposljetku dovelo do promjene priljevnih područja crpilišta (Urumovići dr., 1990; Grđan i Kovačev-Marinčić, 1992; Larva, 2008).

Redovitim monitoringom na crpilištima primijećeno je da kakvoća podzemne vode ne ovisi samo o lokaciji crpilišta nego i o dubini uzorkovanja, odnosno dubini zdenaca. Naime, Varaždinski vodonosnik podijeljen je slabopropusnim slojem na gornji (prvi) i donji (drugi) vodonosni sloj (slika 2. i slika 3.). Cilj ovog rada je utvrditi odnos između koncentracije nitrata u podzemnoj vodi iz gornjeg i donjeg vodonosnog sloja te dinamiku i trend promjena koncentracije. Stoga su analizirani su i međusobno uspoređeni vremenski nizovi godišnjih prosjeka koncentracije nitrata na različitim lokacijama, i to na crpilištima Varaždin, Bartolovec, Vinokovščak, Nedelišće i Prelog, i za svaki vodonosni sloj zasebno. Pored toga provjereno je da li je razlika između koncentracije nitrata u podzemnoj vodi iz tih vodonosnih slojeva značajna u statističkom smislu.

\section{VARAŽDINSKI VODONOSNIK}

Varaždinski vodonosnik (slika 1.) se nalazi u krajnjem zapadnom rubu Dravske doline. Obuhvaća nizinsko područje omeđeno sa sjevera brežuljcima gornjeg Međimurja, na zapadu državnom granicom s Republikom Slovenijom i Viničkim gorjem, a na jugu sjevernim obroncima Varaždinsko-topličkog gorja i Kalnika. 


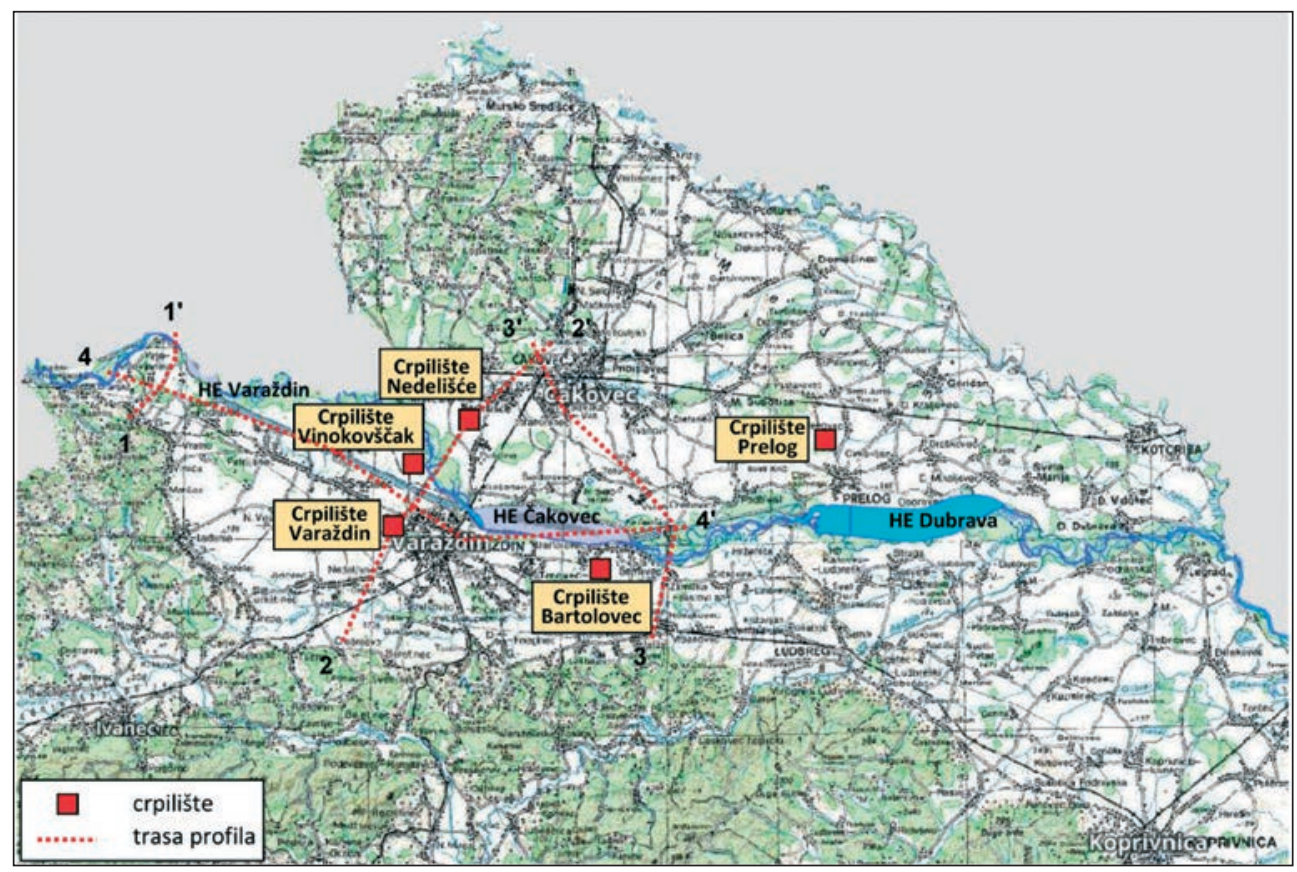

Slika 1. Lokacije crpilišta (http://geoportal.dgu.hr/)

Prema geotektonskoj podjeli to se područje nalazi u Varaždinskoj depresiji čije su bočne granice, kao i istočna granica prema Legradskom pragu, rasjednog karaktera. Vodonosnik je izgrađen pretežno od šljunaka i pijesaka vjerojatno srednje i gornjopleistocenske te holocenske starosti (Urumović i dr., 1990).

U podini vodonosnika se $u$ najzapadnijem području nalaze lapori i pješčenjaci dok su u središnjim dijelovima najčešće nabušeni glina i prah, zatim prašinasti pijesak, lapor i nešto lignita. Krovina je izgrađena od praha, gline i prašinastog pijeska holocenske starosti. Debljina krovine kreće se pretežno od 1-2 m dok je na području zapadno od Varaždina te u području uz rijeku Dravu i manja od $1 \mathrm{~m}$ pa krovinski pokrivač često čini samo humusni sloj. Veće debljine, čak do $9 \mathrm{~m}$, javljaju se uz južni rub, a lokalna zadebljanja moguća su i drugdje.

Vodonosnik je izdužen paralelno toku rijeke Drave i debljina mu se povećava od zapada prema istoku (slika 2.). Debljina vodonosnika je najmanja u području između Križovljana i Ormoža. Uz sjeverni rubni rasjed, na hrvatskoj obali Drave, iznosi oko $5 \mathrm{~m}$, a prema jugu uz južni rubni rasjed raste do preko $15 \mathrm{~m}$ (slika 3.). Prema istoku debljina vodonosnika postupno se povećava. Kod Svibovca (strojarnica HE Varaždin) kreće se oko $30 \mathrm{~m}$ da bi zapadnim rubovima Varaždina dosegla 65 m, a nizvodnije između Orehovice i Zamlake (strojarnica HE Čakovec) premašuje $110 \mathrm{~m}$ 
(slika 2.) (Urumović i dr., 1990). U najdubljem dijelu Varaždinske depresije, južno od Preloga, procijenjena je na temelju geofizičkih podataka na nešto manje od $150 \mathrm{~m}$ (Urumović, 1971). Prema istoku dubina zalijeganja podine vodonosnika opada i kod Svete Marije (strojarnica HE Dubrava) se kreće oko $60 \mathrm{~m}$. Idući od središnjih dijelova depresije prema bočnim granicama debljina vodonosnika postupno se smanjuje (slika 3.). U južnom rubnom području opada na manje od $10 \mathrm{~m}$.

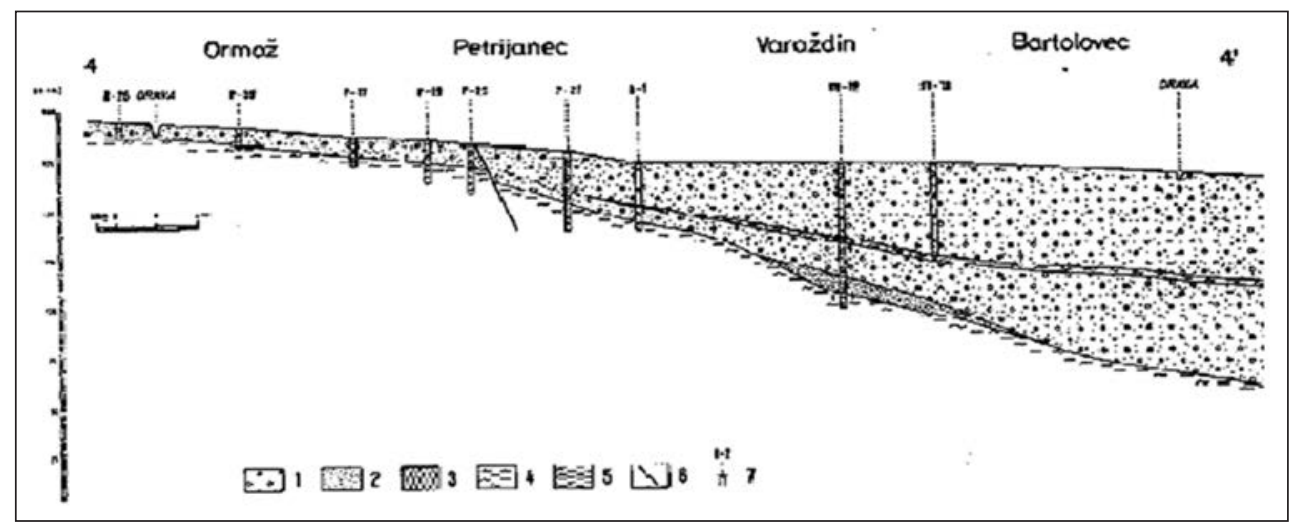

Slika 2. Uzdužni litološki profil Varaždinskog vodonosnika. Tumač oznaka: 1. šljunak, 2. pijesak, 3. prah, 4. glina, 5. lapor, 6. rasjed, 7. bušotina (preuzeto iz Urumović i dr., 1990)

U granulometrijskom sastavu vodonosnika prevladavaju valutice šljunka s različitim postotkom pijeska. Općenito se idući od zapada prema istoku u prosjeku postupno smanjuje veličina zrna, a raste njihova sortiranost. Udio pijeska povećava se naročito u području prema rijeci Muri.

Varaždinski vodonosnik podijeljen je slojem sitnozrnatijeg materijala izgrađenog od gline i praha, mjestimice prašinastog pijeska te treseta na dva šljunčana sloja (slika 2. i slika 3.). Spomenuti međusloj javlja se na dubini $22 \mathrm{~m}$ kod Svibovca, na $55 \mathrm{~m}$ između Zamlake i Orehovice te oko $30 \mathrm{~m}$ kod Svete Marije. Debljina mu se uglavnom kreće od 2 do $5 \mathrm{~m}$. Najveća debljina utvrđena je na jugoistočnoj periferiji Varaždina gdje iznosi 6,9 m (Grđan i Hudoletnjak, 2002). Zapadno od crpilišta Varaždin i Svibovca te duž južnog rubnog područja isklinjuje. Slabopropusni međusloj ima važnu hidrauličku ulogu jer dijeli Varaždinski vodonosnik na dva vodonosna sloja: prvi (gornji) i drugi (donji).

Prvi vodonosni sloj je većinom otvorenog tipa. Tek se u okolici Bartolovca mjestimice nalazi pod tlakom (Larva, 2008). Obnavljanje podzemne vode odvija se infiltracijom oborina kroz nesaturiranu zonu te procjeđivanjem vode iz akumulacijskih 
jezera hidroelektrana i starog korita rijeke Drave. Drugi vodonosni sloj je poluzatvorenog tipa i obnavljanje podzemne vode odvija se procjeđivanjem iz prvog vodonosnog sloja kroz slabopropusni međusloj te na području gdje on isklinjuje.

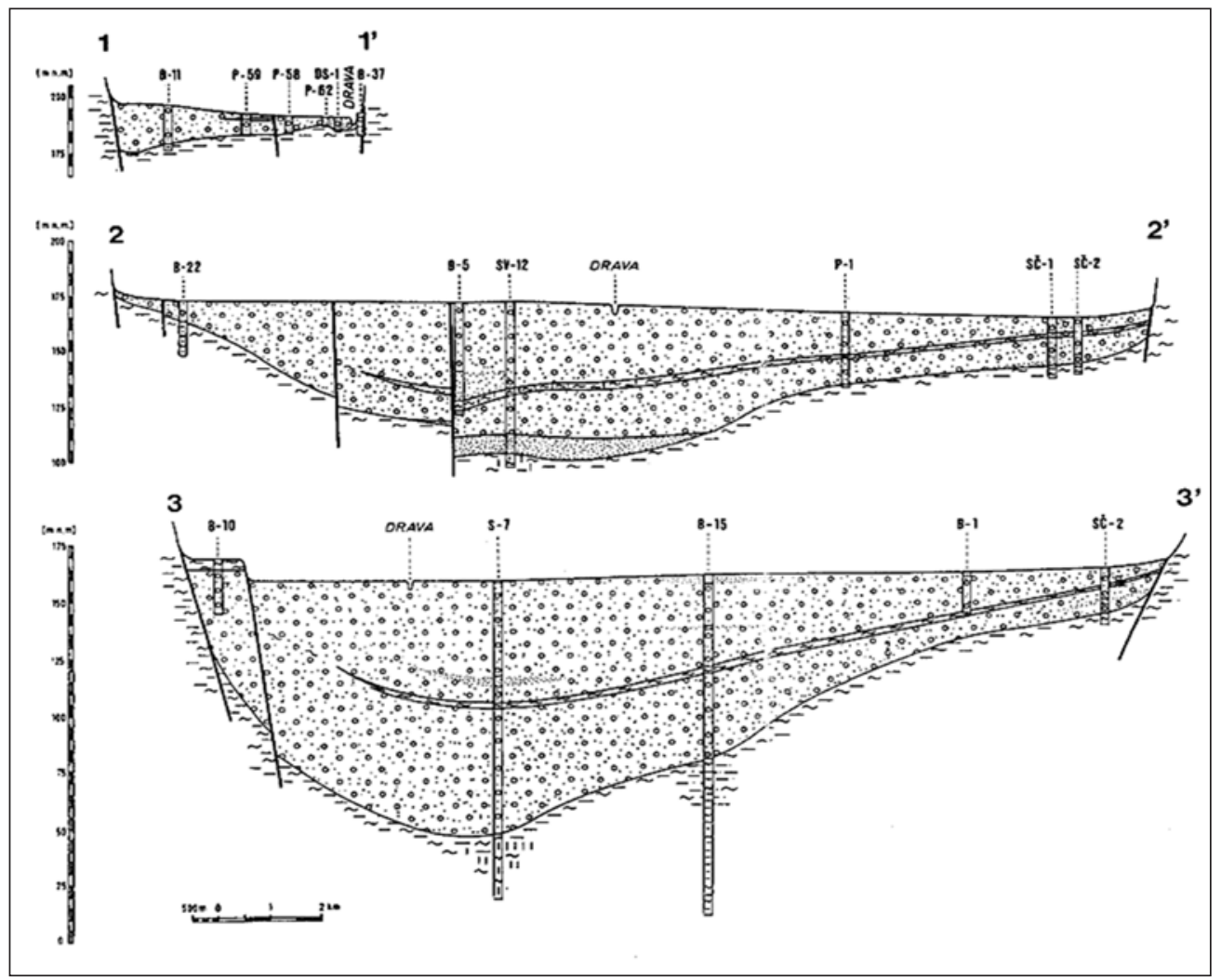

Slika 3. Poprečni litološki profili Varaždinskog vodonosnika (preuzeto iz Urumović i dr., 1990)

Drava je usjekla korito u šljunčani vodonosnik pa je u izravnoj je hidrauličkoj vezi s podzemnom vodom. U najuzvodnijem dijelu toka, približno do Petrijanca, korito presijeca vodonosnik po čitavoj debljini dok je nizvodno urezano samo u njegov površinski dio. Tok podzemne vode odvija se generalno u smjeru istoka-jugoistoka i paralelan je Dravi. Prije izgradnje hidroelektrana većim dijelom godine prevladavalo je otjecanje podzemne vode u Dravu (Urumović i dr., 1990). Nakon punjenja akumulacijskih jezera hidroelektrana razine podzemne vode $\mathrm{u}$ njihovom zaobalju trajno su povišene, dok su u zaobalju odvodnog kanala, koji je neobložen i izveden u 
usjeku, trajno snižene. Na taj su način promijenjeni smjerovi tečenja podzemne vode tako da se procjeđivanjem iz jezera odvija prihranjivanje vodonosnika, a odvodni kanali ga dreniraju. Njihov utjecaj seže do nekoliko kilometara. Dovodni kanal je u potpunosti obložen pa nije u hidrauličkoj vezi s podzemnom vodom (Grđan, 1989; Grđan i Kovačev, 1989; Grđan i Kovačev-Marinčić, 1992).

Hidraulička vodljivost gornjeg vodonosnika kreće se u rasponu od 160-330 m/ dan. Najveću propusnost vodonosnik ima na krajnjem zapadu u području Otoka Virje, a nizvodno se postupno smanjuje. U rubnim predjelima, uz padine Ravne gore i Varaždinsko-Topličkog gorja, procijenjene su vrijednosti u rasponu 10-50 m/dan. Hidraulička vodljivost donjeg vodonosnog sloja kreće se od 40-55 m/dan. Transmisivnost prvog vodonosnog sloja povećava se idući od zapada prema istoku od $1650 \mathrm{~m}^{2} /$ dan na krajnjem zapadnom dijelu do $15000 \mathrm{~m}^{2} /$ dan na području crpilišta Bartolovec (Larva, 2008).

\section{VREMENSKI NIZOVI GODIŠNJIH PROSJEKA KONCENTRACIJE NITRATA}

Kakvoća podzemne vode na svim crpilištima prati se uzorkovanjem vode iz aktivnih zdenaca $u$ pravilu jednom tjedno. Na taj se način tijekom godine prikupi dovoljno podataka za pouzdanu statističku analizu. Na osnovi podataka prikupljenih tijekom jedne godine izračunat je pripadni godišnji prosjek koncentracije nitrata te je za svako crpilište izrađen vremenski niz koji prikazuje promjene tijekom promatranog razdoblja. Podaci o koncentraciji nitrata u podzemnoj vodi iz zdenaca na crpilištu Varaždin, Bartolovec i Vinokovščak dobiveni su od tvrtke Varkom d.d., Varaždin, a na crpilištu Nedelišće i Prelog od tvrtke Međimurske vode d.o.o., Čakovec.

\section{Crpilište Varaždin}

Crpilište Varaždin je smješteno na zapadnom rubu grada (slika 1.), a započelo je s radom 1963. godine nakon što su izrađeni kopani zdenci B-1 i B-2. U razdoblju od 1970. do 1978. godine izvedeno je još osam bušenih zdenaca dubine između 35,5 i 38 m (Piasek i dr., 2013). Svih 10 zdenaca zahvaća vodu samo iz prvog (plitkog) vodonosnika. 


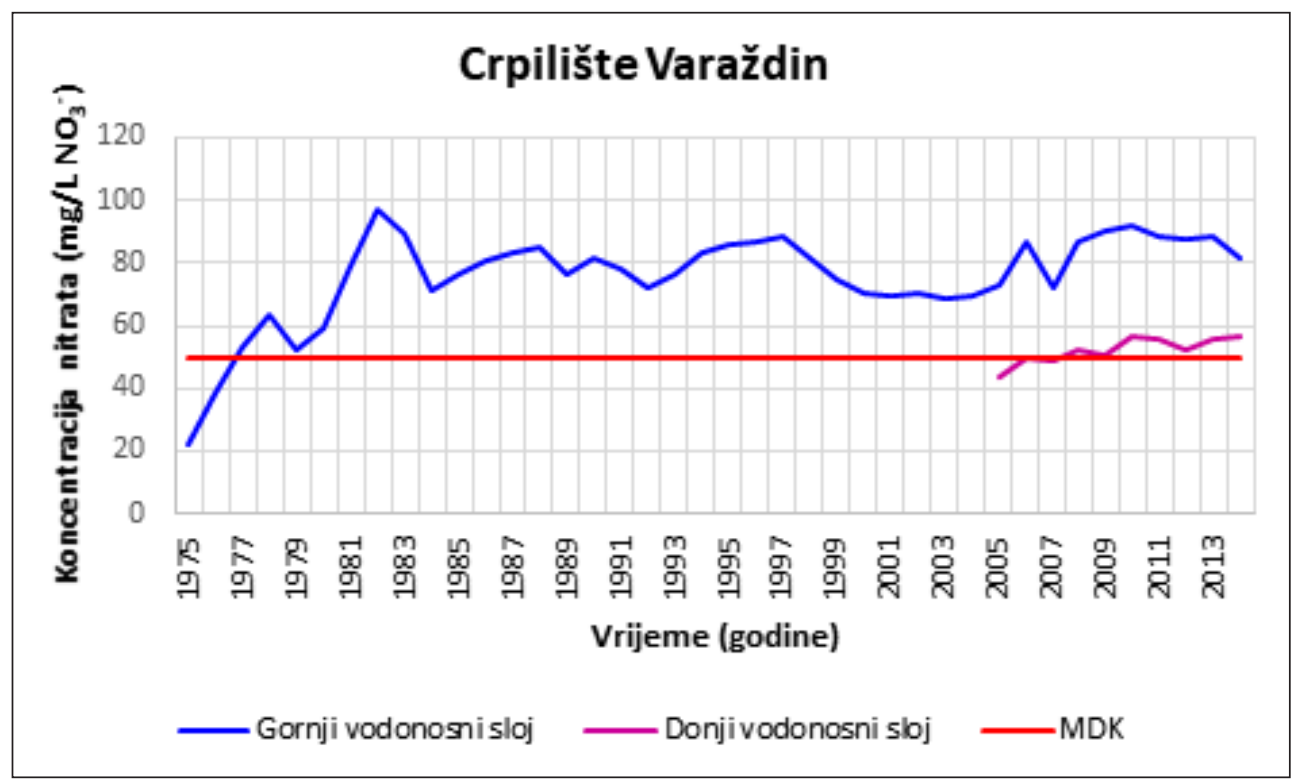

Slika 4. Vremenski nizovi godišnjih prosjeka koncentracije nitrata na crpilištu Varaždin

Inicijalna koncentracija nitrata u podzemnoj vodi iz plitkih zdenaca na crpilištu Varaždin 1973. godine kretala se oko 4,4 mg/L $\mathrm{NO}_{3}$, odnosno oko $1 \mathrm{mg} / \mathrm{L} \mathrm{N}$ što se može smatrati temeljnom vrijednošću (engl. background level), odnosno koncentracijom u prirodnom stanju bez utjecaja onečišćenja. Već 1976. godine prekoračena je vrijednost MDK, da bi maksimalne vrijednosti bile dosegnute 1982. godine. Povećanje koncentracije nitrata na crpilištu Varaždin dovodi se u vezu s puštanjem u pogon HE Varaždin 1975. godine, a zatim HE Čakovec 1982. godine (Grđan i dr., 1991).

Vremenski nizovi godišnjih prosjeka (slika 4.) pokazuju da je koncentracija nitrata u podzemnoj vodi iz plitkog vodonosnika na crpilištu Varaždin znatno veća od MDK već nekoliko desetljeća, ali je posljednjih godina koncentracija i u donjem sloju također iznad MDK. Koncentracija u gornjem vodonosnom sloju znatno je viša nego u donjem.

\section{Crpilište Bartolovec}

Crpilište Bartolovec nalazi se približno $7 \mathrm{~km}$ istočno od Varaždina i oko $2 \mathrm{~km}$ južno od akumulacijskog jezera HE Čakovec (slika 1.). Započelo je s radom 1972. godine nakon što su izvedena dva plitka bušena zdenca dubine po $29,5 \mathrm{~m}$. Godine 
1991. na crpilištu je izveden prvi duboki zdenac dubine 104,5 m koji crpi vodu samo iz donjeg vodonosnog sloja. Danas je na crpilištu aktivno ukupno osam zdenaca od kojih su četiri duboka i četiri plitka (Piasek i dr., 2013).

Početna koncentracija nitrata na crpilištu Bartolovec sredinom 1971. godine, u vrijeme izvođenja prvih plitkih zdenaca, iznosila je $8,8 \mathrm{mg} / \mathrm{L} \mathrm{NO}_{3}$, odnosno oko 2 $\mathrm{mg} / \mathrm{L} \mathrm{N}$. Već potkraj 1976. godine prekoračene su vrijednosti od $44,3 \mathrm{mg} / \mathrm{L} \mathrm{NO}_{3}$, odnosno $10 \mathrm{mg} / \mathrm{L}$ N. Najveće koncentracije pojavile su se u drugoj polovini 1982. i početkom 1983. godine (Grđan i dr., 1991). Nakon toga prisutan je gotovo neprekidan silazni trend do 2003. godine od kada su se vrijednosti koncentracije nitrata u podzemnoj vodi iz gornjeg vodonosnika ustalile na nešto manje od $20 \mathrm{mg} / \mathrm{L} \mathrm{NO}_{3}$. (slika 5.), što je znatno manje nego u plitkom vodonosniku na crpilištu Varaždin.

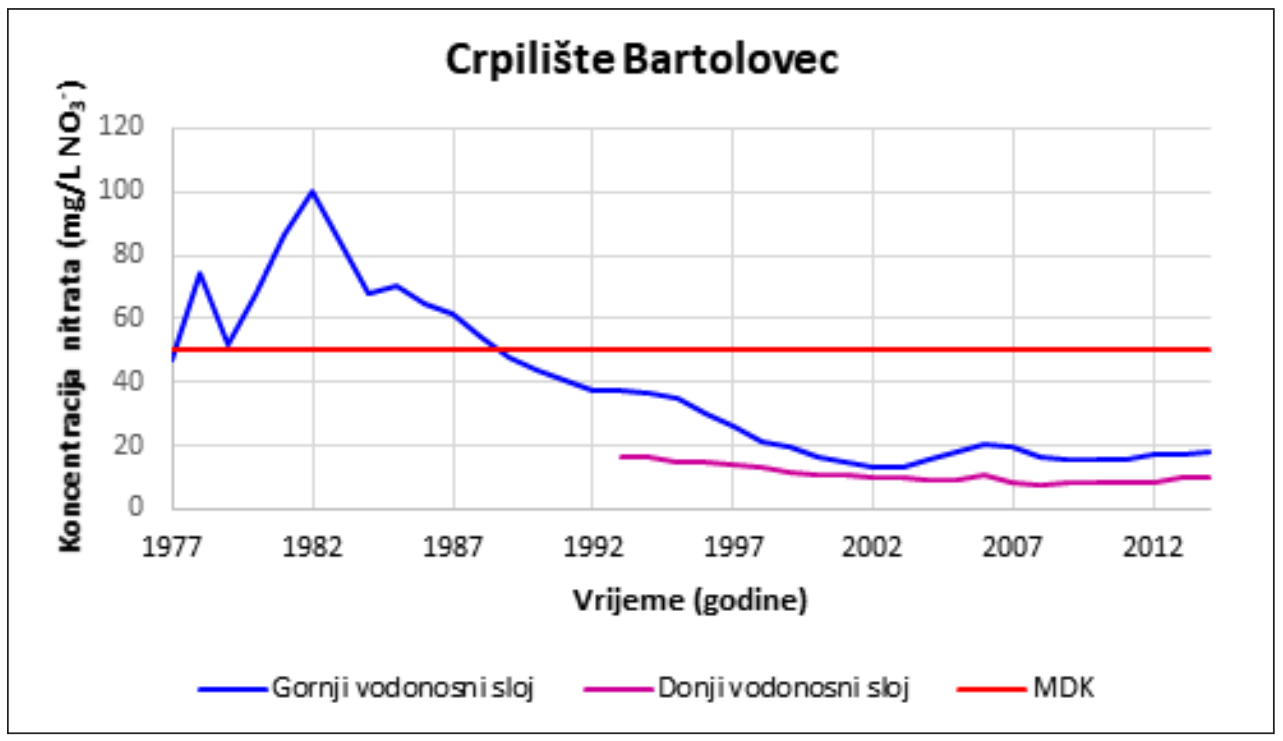

Slika 5. Vremenski nizovi godišnjih prosjeka koncentracije nitrata na crpilištu Bartolovec

I na crpilištu Bartolovec koncentracija nitrata u podzemnoj vodi iz donjeg vodonosnog sloja uvijek je manja nego iz gornjeg, ali je ta razlika manja nego na crpilištu Varaždin (slika 5.). 


\section{Crpilište Vinokovščak}

Crpilište Vinokovščak smješteno je sjeverozapadno od Varaždina u području između starog korita rijeke Drave i odvodnog kanala HE Varaždin (slika 1.). Počelo je s radom 1998. godine i danas ga čine tri aktivna zdenca dubine između 38 i $41 \mathrm{~m}$. Svi zdenci zahvaćaju i prvi i drugi vodonosni sloj što znači da crpljena voda potječe iz oba sloja. Zbog toga je za ovo crpilište izrađen samo jedan vremenski niz godišnjeg prosjeka koncentracije nitrata (slika 6.).

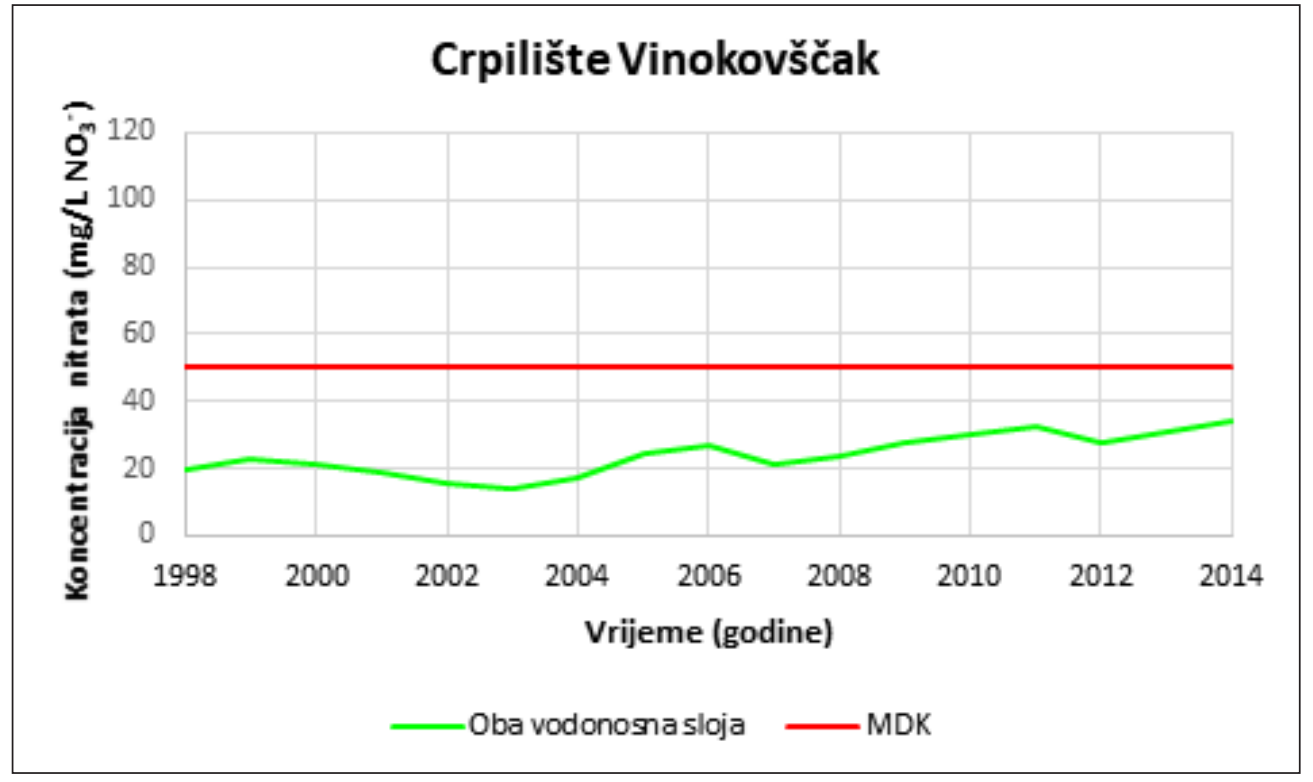

Slika 6. Vremenski niz godišnjeg prosjeka koncentracije nitrata na crpilištu Vinokovščak

Koncentracija nitrata na crpilištu Vinokovščak manja je od MDK. Na početku rada, 1998. godine, koncentracija nitrata na crpilištu Vinokovščak bila je manja u odnosu koncentraciju u gornjem i nešto viša nego u donjem vodonosnom sloju na crpilištu Bartolovec. Vremenski niz godišnjeg prosjeka koncentracije nitrata na crpilištu Vinokovščak pokazuje kako je već dugi niz godina, uz manja kolebanja, prisutan uzlazni trend (slika 6.). Posljednje povećanje koncentracije od 2012. godine moglo bi biti posljedica iste poplave na dijelu toka Drave kao što je slučaj na crpilištu Nedelišće. 


\section{Crpilište Nedelišće}

Crpilište Nedelišće nalazi se jugozapadno od grada Čakovca u trokutu između naselja Nedelišće, Pušćine i Gornji Hraščan (slika 1.). Pušteno je u rad 1977. godine. Crpilište obuhvaća ukupno šest aktivnih zdenaca dubine između $23 \mathrm{~m}$ i $35 \mathrm{~m}$ od kojih jedan crpi vodu iz gornjeg vodonosnog sloja dok ostali crpe vodu iz oba sloja.

Koncentracija nitrata na crpilištu Nedelišće manja je od MDK. Na početku prikazanog razdoblja, 2006. godine (slika 7.) koncentracija se kretala oko $20 \mathrm{mg} / \mathrm{L} \mathrm{NO}_{3^{-}} \mathrm{i}$ smanjivala se sve do 2012. godine kada je bila manja od $10 \mathrm{mg} / \mathrm{L} \mathrm{NO}_{3}$. Nakon toga prisutan je uzlazni trend te se vrijednost koncentracije približava vrijednostima s početka prikazanog razdoblja. Smatra se da je uzrok povećanja koncentracije nitrata od 2012. godine poplava koja se dogodila u Pušćinama u studenome 2012. godine (Glumac, 2016).

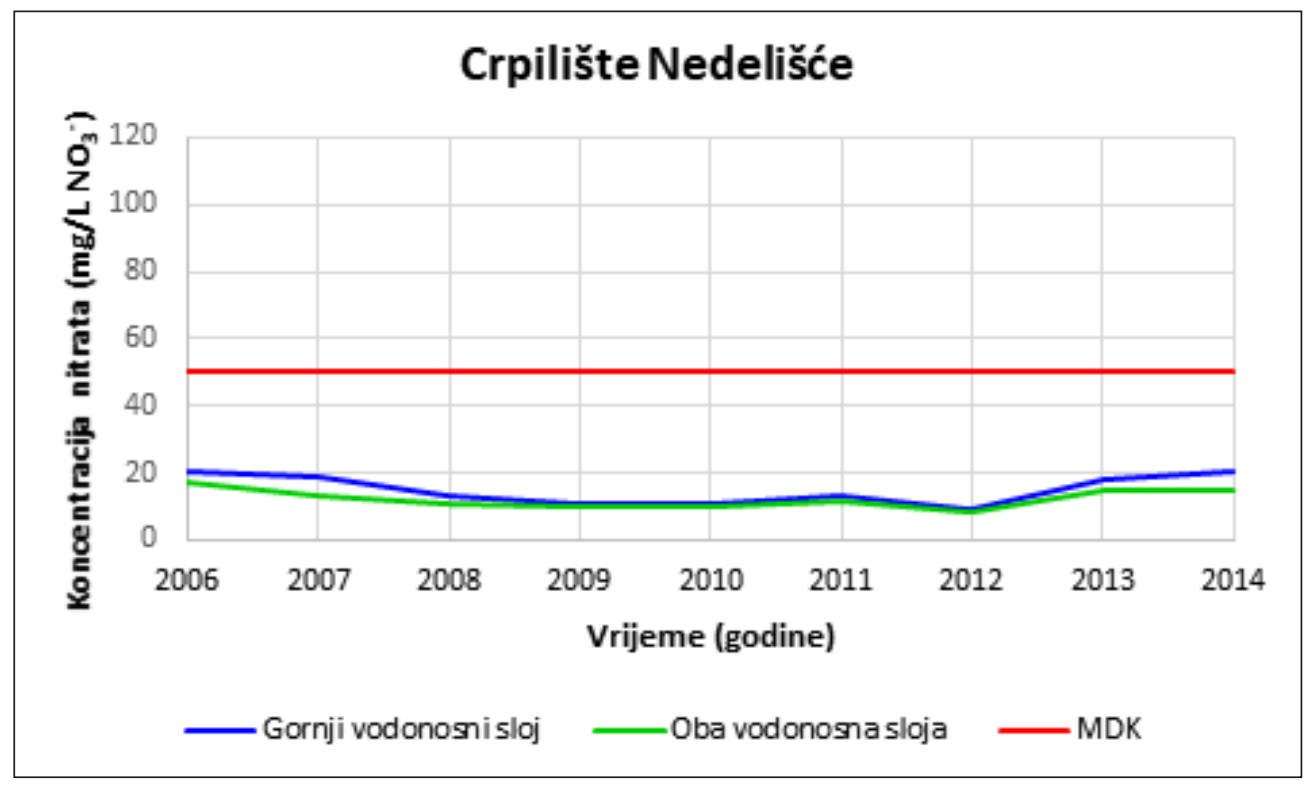

Slika 7. Vremenski niz godišnjeg prosjeka koncentracije nitrata na crpilištu Nedelišće

Na crpilištu Nedelišće nije moguće usporediti koncentracije nitrata u gornjem i donjem vodonosnom sloju jer nema zdenca koji bi crpio vodu samo iz donjeg vodonosnika. Međutim, i na ovoj lokaciji voda iz gornjeg sloja ima veću koncentraciju nitrata u odnosu na vodu iz zdenaca koji crpe vodu iz oba sloja (slika 7.), ali je ta razlika pretežno manja nego na crpilištu Bartolovec. Od 2012. godine razlika se povećava. 


\section{Crpilište Prelog}

Crpilište Prelog smješteno je između grada Preloga te naselja Čehovec i Cirkovljan i udaljeno je oko $2,5 \mathrm{~km}$ od akumulacijskog jezera HE Dubrava (slika 1.). Prvi plitki zdenac dubine $28 \mathrm{~m}$ izveden je 1981. godine, a drugi 1986. godine. Crpilište je započelo s radom 1988. godine kada je u vodoopskrbni sustav uključen prvi plitki zdenac. Od 2012. godine u funkciji je prvi duboki zdenac na crpilištu.

I na crpilištu Prelog koncentracija nitrata je znatno veća u gornjem vodonosnom sloju u odnosu na donji sloj. Međutim, posljednjih nekoliko godina prisutan je trend povećanja koncentracije u oba sloja (slika 8.) kao što je to slučaj na crpilištima Vinokovščak i Nedelišće, ali je taj trend ovdje znatno blaži.

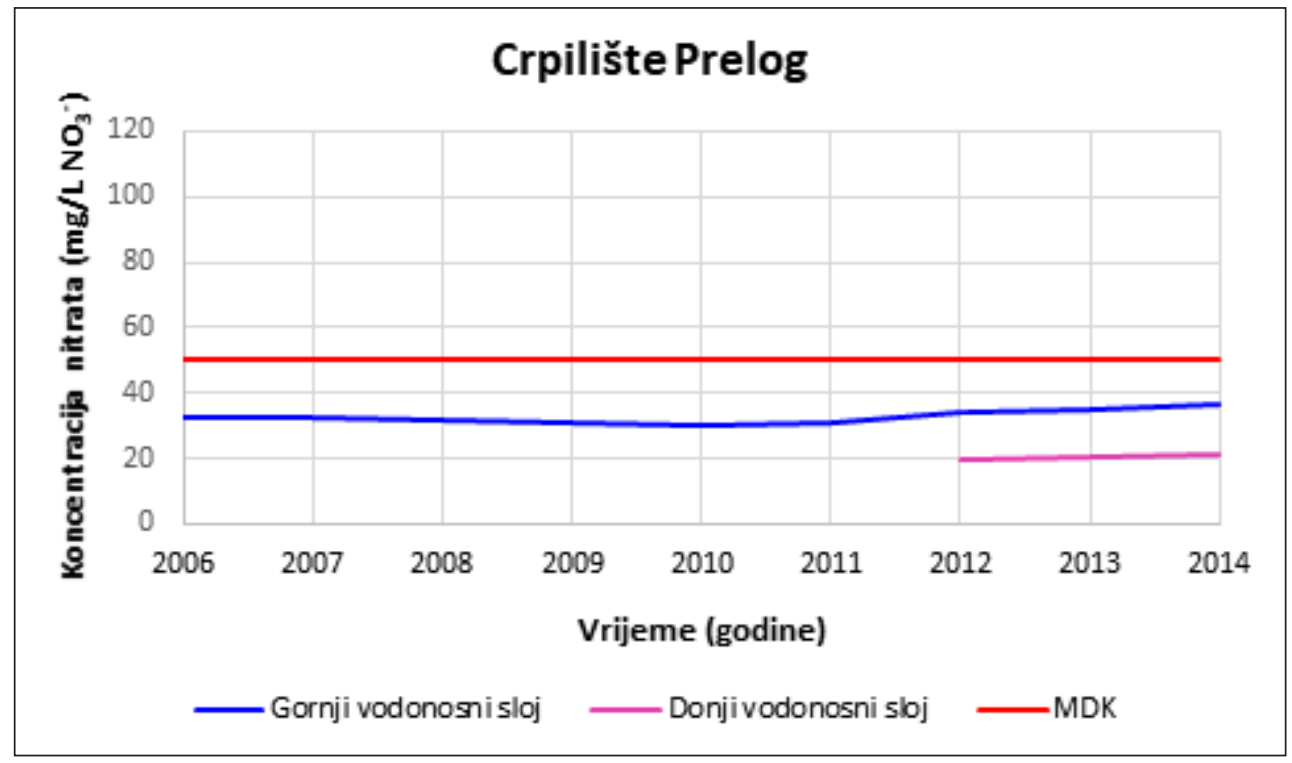

Slika 8. Vremenski niz godišnjeg prosjeka koncentracije nitrata na crpilištu Prelog

\section{ANALIZA RAZLIKE IZMEĐU KONCENTRACIJA NITRATA U GORNJEM I DONJEM VODONOSNOM SLOJU}

Na crpilištima na kojima se podzemna voda crpi zasebno, a to su crpilišta Varaždin, Bartolovec i Prelog, uspoređene su vrijednosti godišnjih prosjeka koncentracije nitrata u podzemnoj vodi iz gornjeg i iz donjeg sloja Varaždinskog vodonosnika. Na svim lokacijama utvrđena je očekivano veća koncentracija u gornjem vodonosnom sloju u odnosu na donji. 


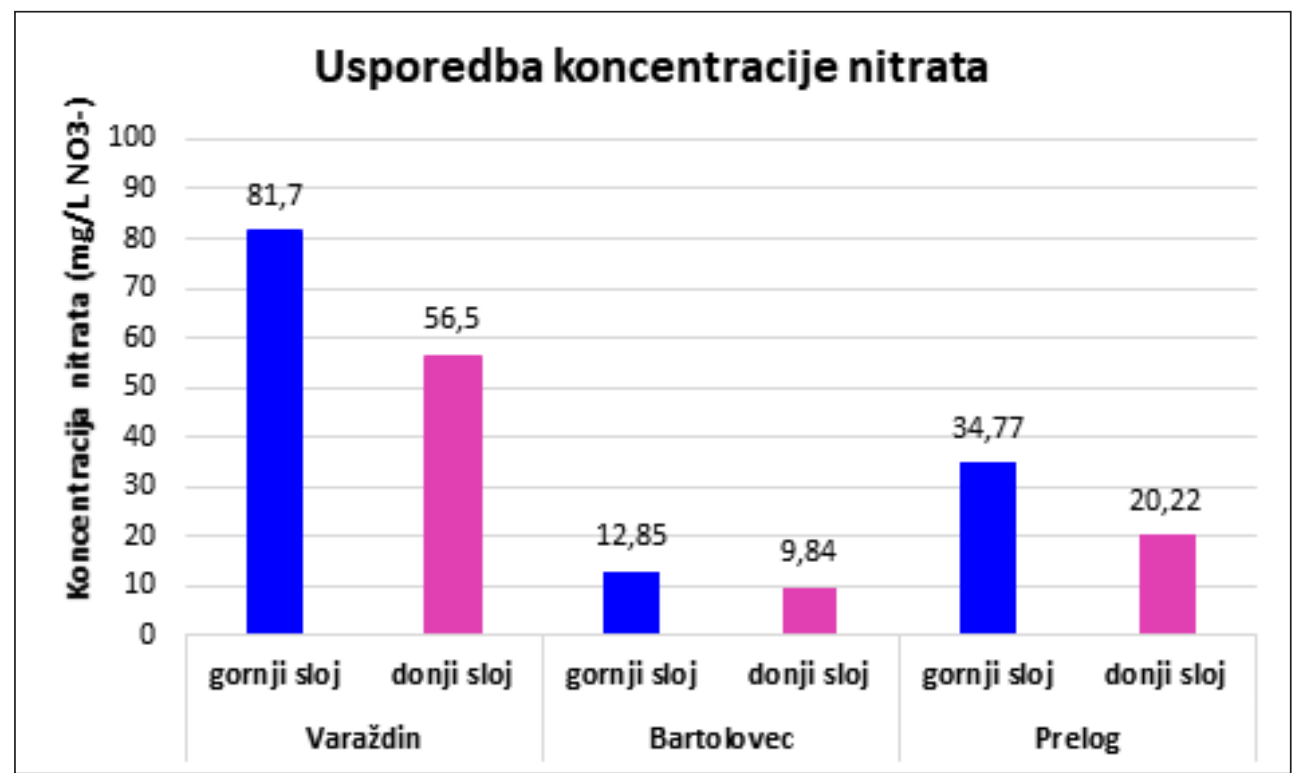

Slika 9. Usporedba godišnjih prosjeka koncentracija nitrata u gornjem i donjem vodonosnom sloju na crpilištima Varaždin, Bartolovec i Prelog

Opravdano je postaviti pitanje je li ta razlika značajna u statističkom smislu. Zbog toga su izdvojene i na slici 9. prikazane vrijednosti godišnjih prosjeka koncentracije nitrata na crpilištima Varaždin, Bartolovec i Prelog za one godine kad je razlika koncentracija u podzemnoj vodi iz gornjeg i iz donjeg vodonosnog sloja bila najmanja. Na crpilištu Varaždin najmanja je razlika zabilježena 2014. godine, na crpilištu Bartolovec 2003. godine, a na crpilištu Prelog 2013. godine.

Za daljnju analizu odabrano je crpilište Bartolovec jer su na toj lokaciji aktivna četiri plitka i četiri duboka zdenca tako da je na raspolaganju najveći broj podataka. Nadalje, na tom je crpilištu zabilježena najmanja razlika između godišnjih prosjeka koncentracije nitrata u gornjem i donjem vodonosnom sloju koja iznosi 3,01 mg/L $\mathrm{NO}_{3}$ i odnosi se na 2003. godinu (slika 10.). 


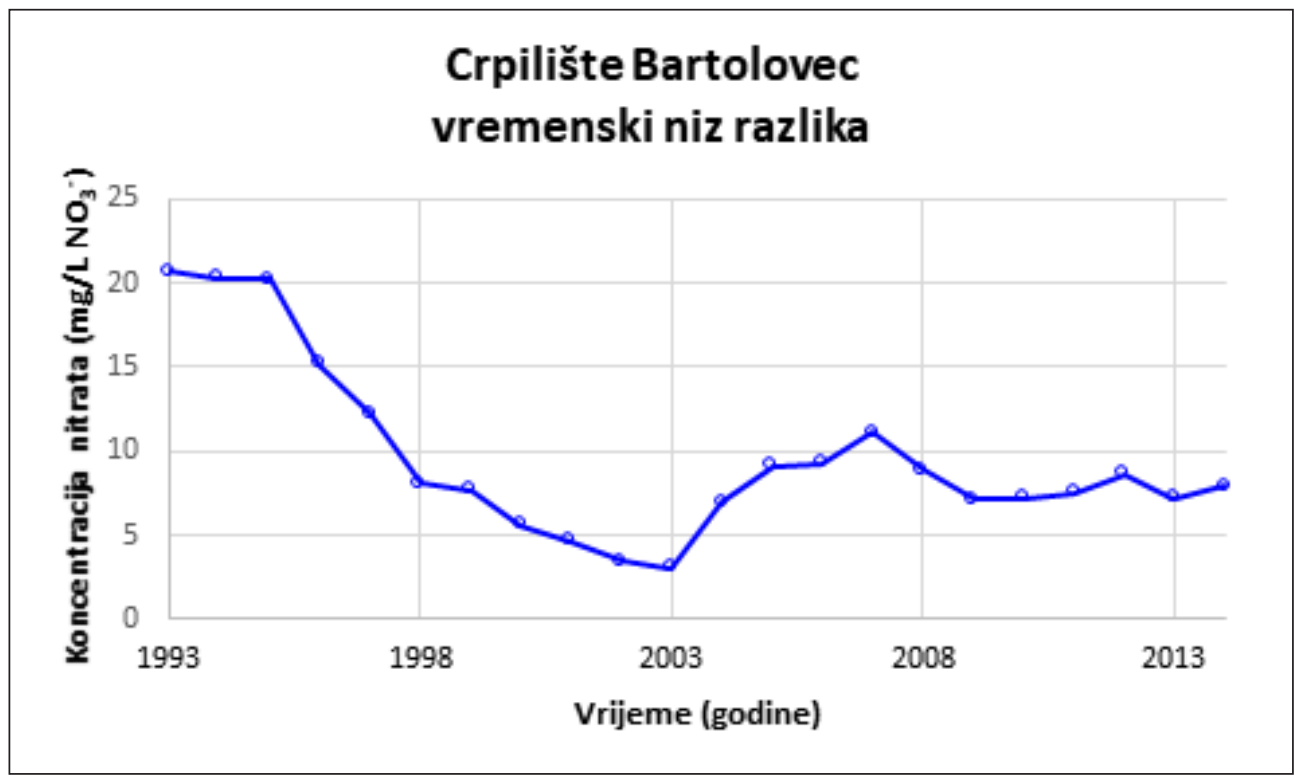

Slika 10. Vremenski niz razlika između godišnjih prosjeka koncentracije nitrata u gornjem i donjem vodonosnom sloju na crpilištu Bartolovec

Da bi se utvrdila značajnost razlike između koncentracija nitrata u gornjem i donjem vodonosnom sloju, primijenjen je t-test. Godišnji prosjek koncentracije nitrata u gornjem sloju 2003. godine iznosio je $12,85 \mathrm{mg} / \mathrm{L} \mathrm{NO}_{3^{-}}$, a u donjem 9,84 $\mathrm{mg} / \mathrm{L} \mathrm{NO}_{3}$. Pripadne standardne devijacije iznosile su 2,93 mg/L NO${ }_{3^{-}}$, odnosno 4,48 $\mathrm{mg} / \mathrm{L} \mathrm{NO}_{3}$.. S obzirom da je tijekom te godine podzemna voda na crpilištu Bartolovec uzorkovana 72 puta iz gornjeg i 94 puta iz donjeg vodonosnog sloja, t-vrijednost je izračunata za velike nezavisne uzorke prema izrazu (Petz, 1997):

$$
t=\frac{\bar{x}_{g}-\bar{x}_{d}}{s_{\bar{x}}-\bar{x}_{d}}
$$

gdje je: $\bar{x}_{g}-\bar{x}_{d}-$ razlika između godišnjih prosjeka koncentracije nitrata u gornjem i donjem vodonosnom sloju koja iznosi 3,01 mg/L NO${ }_{3}, s_{\bar{x}_{g}-\bar{x}_{d}}$ - pripadna standardna greška razlike koja iznosi $0,58 \mathrm{mg} / \mathrm{L} \mathrm{NO}_{3}$.

Izračunata t-vrijednost iznosi 5,28. Kritična t-vrijednost očitana je iz tablice (Petz, 1997) na osnovi razine signifikantnosti testa od 0,05 i broja stupnjeva slobode $(d f=164)$ i iznosi 2,35. S obzirom da je kritična t-vrijednost manja od izračunate, 
razlika između godišnjih prosjeka koncentracije nitrata u gornjem i donjem vodonosnom sloju je statistički značajna.

U svim ostalim godinama promatranog razdoblja razlika između godišnjih prosjeka na crpilištu Bartolovec, kao i na ostalim crpilištima, je veća. Osim toga, ako bi se u uzorak za gornji, odnosno donji vodonosni sloj uključili rezultati iz svih godina kada je praćena kakvoća podzemne vode, tada bi razlika između izračunate i kritične t-vrijednosti bila još veća. Stoga se može zaključiti da je razlika između koncentracija nitrata u gornjem i donjem vodonosnom sloju statistički značajna, odnosno da je koncentracija nitrata u podzemnoj vodi u gornjem vodonosnom sloju značajno viša u odnosu na koncentraciju u donjem sloju.

\section{ZAKLJUČAK}

Na području Varaždinske i Međimurske županije nalazi se pet crpilišta namijenjenih za javnu vodoopskrbu na kojima se podzemna voda crpi iz Varaždinskog vodonosnika. Podzemna voda zahvaća se zasebno iz gornjeg i iz donjeg vodonosnog sloja na crpilištima Varaždin, Bartolovec i Prelog dok na crpilištima Vinokovščak i Nedelišće zdenci zahvaćaju oba sloja. Sa stanovišta kakvoće podzemne vode Varaždinskog vodonosnika problematične su povišene koncentracije nitrata. Vremenski nizovi godišnjih prosjeka pokazali su da je koncentracija nitrata na svim crpilištima veća u podzemnoj vodi iz gornjeg vodonosnika nego iz donjeg. Najkritičnije je stanje na crpilištu Varaždin gdje je koncentracija nitrata u plitkom vodonosniku povećana do te mjere da je već nekoliko desetljeća prekoračena najveća dopuštena koncentracija, dok je u donjem vodonosnom sloju znatno niža, ali također veća od MDK. Na svim ostalim crpilištima vrijednosti koncentracije nitrata su ispod MDK.

U gornjem vodonosniku na crpilištu Bartolovec utvrđen je gotovo neprekidan silazni trend od maksimalnih vrijednosti koje su registrirane 1982./1983. do 2003. godine nakon čega su se koncentracije nitrata ustalile na nešto manje od $20 \mathrm{mg} / \mathrm{L}$ $\mathrm{NO}_{3}$. Slične vrijednosti godišnjih prosjeka dobivene su i na crpilištu Nedelišće, ali od 2012. godine, kada se dogodila poplava u Pušćinama, imaju tendenciju porasta. Uzlazni trend uz manja kolebanja prisutan je i na crpilištu Vinokovščak, a posljednje povećanje koncentracije također bi moglo biti posljedica iste poplave na tom dijelu toka Drave. Blagi porast koncentracije nitrata također od 2012. godine utvrđen je i na crpilištu Prelog.

Pomoću t-testa ispitano je da li je razlika između godišnjih prosjeka koncentracija nitrata u gornjem i donjem vodonosnom sloju značajna u statističkom smislu. Za analizu je odabrano crpilište Bartolovec jer se podzemna voda crpi zasebno iz svakog vodonosnog sloja i na raspolaganju je najveći broj podataka. Osim toga, na tom je crpilištu 2003. godine zabilježena najmanja razlika između godišnjih prosjeka 
koncentracije nitrata u gornjem i donjem vodonosnom sloju. S obzirom da je tijekom te godine podzemna voda na crpilištu Bartolovec uzorkovana 72 puta iz gornjeg i 94 puta iz donjeg vodonosnog sloja, t-vrijednost je izračunata prema izrazu za velike nezavisne uzorke i iznosi 5,28, a kritična t-vrijednost je manja te iznosi 2,35. U svim ostalim godinama promatranog razdoblja razlika između godišnjih prosjeka na crpilištu Bartolovec, kao i na ostalim crpilištima, je veća. Osim toga, ako bi se u uzorak za gornji, odnosno donji vodonosni sloj uključili rezultati iz svih godina kada je praćena kakvoća podzemne vode, tada bi razlika između izračunate i kritične t-vrijednosti bila još veća.

Stoga se može zaključiti da je razlika između koncentracije nitrata u gornjem i donjem vodonosnom sloju statistički značajna, odnosno da je koncentracija nitrata u podzemnoj vodi u gornjem vodonosnom sloju značajno viša u odnosu na koncentraciju u donjem sloju. To nadalje ukazuje na veću izloženost gornjeg sloja onečišćenju i veću zaštitu donjeg sloja od onečišćenja koju pruža slabopropusni međusloj.

\section{LITERATURA}

1. G. GJETVAJ (1993): „Identifikacija porijekla nitrata u podzemnim vodama Varaždinske regije." Hrvatske vode, 1 (4), 247-252, Zagreb.

2. N. GLUMAC (2016): „Izvješće o kvaliteti vode za ljudsku potrošnju za 2015. godinu." Međimurske vode, Čakovec (http://medjimurske-vode.hr/analiza-vode/, preuzeto 21.03.2016.).

3. D. GRĐAN (1989): „Utjecaj površinskih akumulacija na režim podzemnih voda (na primjeru akumulacija na rijeci Dravi).“ Disertacija, Rudarsko-geološko-naftni fakultet, Sveučilište u Zagrebu, 108 str., Zagreb.

4. D. GRĐAN, P. DURMAN i B. KOVAČEV-MARINČIĆ (1991): „Odnos promjene režima i kvalitete podzemnih voda na crpilištima Varaždin i Bartolovec.", Geol. vjesnik, 44, 301-308, Zagreb.

5. D. GRĐAN i V. HUDOLETNJAK (2002): „Utjecaj hidrogeoloških uvjeta u varaždinskom vodonosnom sloju na kvalitetu vode vodoopskrbnog sustava Varaždin." Zbornik radova međunarodnog znanstvenog simpozija Stvaralački potencijali u funkciji društveno-ekonomskog i kulturnog razvoja sjeverozapadne Hrvatske, 21.-22. studeni 2002. Hrvatska akademija znanosti i umjetnosti - Zavod za znanstveni rad Varaždin, 325-339.

6. D. GRĐAN i B. KOVAČEV (1989): „Utjecaj HE Varaždin na režim podzemnih voda u desnom zaobalju Drave kod Virje Otoka." Geol. vjesnik, 42, 249-258, Zagreb. 
7. D. GRĐAN i B. KOVAČEV-MARINČIĆ (1992): „Effects of the Čakovec hydroelectric power plant on groundwater system. ", Rudarsko-geološko-naftni zbornik, 4, 37-45, Zagreb.

8. http://geoportal.dgu.hr/ (pristupljeno 19.05.2016.)

9. I. KOVAČ (2004): „Statističko-variografska analiza kemijskog sastava podzemne vode varaždinske regije." Disertacija, Rudarsko-geološko-naftni fakultet, Sveučilište u Zagrebu, 123 str., Zagreb.

10. Laboratorijski nalazi vode za razdoblje 1975.-2014., Varkom d.d. Varaždin, Laboratorij za pitke vode.

11. Laboratorijski nalazi vode za razdoblje 2006.-2014., Međimurske vode d.o.o., Čakovec.

12. O. LARVA (2008): „Ranjivost vodonosnika na priljevnom području varaždinskih crpilišta.", Disertacija, Rudarsko-geološko-naftni fakultet, Sveučilište u Zagrebu, 194 str., Zagreb.

13. T. MARKOVIĆ, O. LARVA, S. KAPELJ I Ž. BRKIĆ (2007): Chicken waste or synthetic fertilizers? Using stable nitrogen and oxygen isotopes to trace groundwater pollution. Second International Conference on Waters in Protected Areas / Z. Nakić (ed.), Kopriva-graf, Zagreb.

14. B. PETZ. (1997): Osnovne statističke metode za nematematičare. Naklada Sklap. Zagreb.

15. Z. PIASEK, T. BOŽIĆ, T. VUSIĆ, I Z. MEHUN (2013): Varkom. Monografija. TIVA d.o.o. Varaždin.

16. Pravilnik o parametrima sukladnosti i metodama analize vode za ljudsku potrošnju (NN 125/2013,141/2013, 128/2015)

17. M. ŠRAJBEK (2011a): „Kvantifikacija utjecaja zagađivača na koncentraciju nitrata u podzemnoj vodi varaždinske regije.", Rad za rektorovu nagradu, Geotehnički fakultet, Sveučilište u Zagrebu, 38 str., Varaždin.

18. M. ŠRAJBEK (2011b): „Procjena utjecaja zagađivača na kvalitetu podzemne vode.“, Diplomski rad, Geotehnički fakultet, Sveučilište u Zagrebu, 51 str., Varaždin.

19. K. URUMOVIĆ (1971): „O kvartarnom vodonosnom kompleksu na području Varaždina.", Geol. vjesnik, 24, 183-188, Zagreb.

20. K. URUMOVić, B. HLEVNJAK, E. PRElOGOVIĆ, D. MAYER (1990): „Hidrogeološki uvjeti Varaždinskog vodonosnika.“, Geol. vjesnik, 43, 149-158, Zagreb. 


\section{SAŽETAK \\ KOMPARATIVNA ANALIZA KONCENTRACIJE NITRATA U GORNJEM I DONJEM SLOJU VARAŽDINSKOG VODONOSNIKA}

U radu su analizirani vremenski nizovi godišnjih prosjeka koncentracije nitrata na pet crpilišta u Varaždinskoj i Međimurskoj županiji. Koncentracija nitrata analizirana je zasebno za gornji i donji vodonosni sloj Varaždinskog vodonosnika. Na osnovi vremenskih nizova je utvrđeno da je koncentracija nitrata na svim crpilištima veća u gornjem vodonosnom sloju i da ne prelazi maksimalno dopuštenu koncentraciju (MDK) od $50 \mathrm{mg} / \mathrm{L} \mathrm{NO}_{3}$-osim na crpilištu Varaždin gdje je povišena već nekoliko desetljeća.

Pomoću t-testa ispitana je statistička značajnost razlika između godišnjih prosjeka koncentracija nitrata u gornjem i donjem vodonosnom sloju. Analiza je provedena za crpilište Bartolovec u 2003. godinu kada je ta razlika tijekom promatranoga razdoblja bila najmanja. Izračunata t-vrijednost bila je veća od kritične. Stoga je zaključeno da je razlika između godišnjih prosjeka koncentracije nitrata u gornjem i donjem sloju Varaždinskog vodonosnika statistički značajna.

Ključne riječi: Varaždinski vodonosnik; gornji i donji vodonosni sloj; podzemna voda; koncentracije nitrata; vremenski nizovi; t-test.

\section{SUMMARY}

\section{COMPARATIVE ANALYSIS OF NITRATE CONCENTRATION IN UPPER AND LOWER AQUIFER OF THE VARAŽDIN SYSTEM OF AQUIFERS}

Time series of annual averages of nitrate concentration in five well fields in the Counties of Varaždin and Međimurje were analised in the paper. The nitrate concentration was analised separetly in the upper and the lower aquifer of the Varaždin system of aquifers. On the basis of the time series, it was found out that the nitrate concentration is higher in the upper aquifer at the all well fields. The MAC (maximum admissible concentration) was not exceeded, except at the Varaždin well field, where the concentration has been heightened for several decades.

The statistical significance of the difference between the annual averages of the nitrate concentration in the upper and the lower aquifer was defined by t-test. The analysis was carried out for the Bartolovec well field in 2003 when the difference was the smallest during the period of monitoring. The calculated t-value was larger than the critical one. Therefore, it was concluded that the difference between the annual averages of the nitrate concentrations in the upper and the lower aquifer of the Varaždin system of aquifers is statistically significant.

Key Words: Varaždin system of aquifers; upper and downer aquifer; groundwater; nitrate concentration; time series; t-test. 